Холод С. Г., науковий співробітник

Устимівська дослідна станція рослинництва

\title{
ПРОЯВ ОЗНАКИ «УРОЖАЙНІСТЬ» ТА ЇЇ ЕЛЕМЕНТІВ У КОЛЕКЦЙНИХ ЗРАЗКІВ ПРОСА РІЗНОГО ЕКОЛОГО-ГЕОГРАФІЧНОГО ПОХОДЖЕННЯ В УМОВАХ ПІВДЕННОГО ЛІСОСТЕПУ УКРАЇНИ
}

\author{
Рецензент - кандидат сільськогосподарських наук О. В. Тригуб
}

\begin{abstract}
Наведено результати трирічного вивчення набору колекиійних зразків проса, різних за походженням (із 34 країн світу) $і$ біологічним статусом (місиеві й селекиійні сорти, лінії) за ознакою «урожайність» та ії складовими елементами в контрастних погодних умовах вирощування. Визначено коефіиієнти варіації та кореляційні зв'язки між даними показниками. Найбільш врожайними виявилися зразки походженням з України, Японії, Індії, Марокко і Франиії. Виділено 20 високоврожайних зразків проса зі стабільним проявом за роками, рекомендовані як вихідний матеріал для селекиії на стабілізацію урожайності.
\end{abstract}

Ключові слова: просо, колекція, зразки, урожайність, елементи урожайності, варіація, корелячія, вихідний матеріал.

Постановка проблеми. Важливим завданням у селекції проса $є$ створення сортів із високим потенціалом продуктивності та стабільності урожаїв, із позитивною реакцією на оптимальні екологічні умови.

Успішна селекція передбачає добір вихідного матеріалу 3 високою продуктивністю, що при схрещуванні комбінується 3 іншими цінними ознаками й відповідає перспективним напрямам селекційного процесу. Селекція на високу врожайність $є$ досить складною, поскільки дана ознака залежить від багатьох біологічних властивостей рослини. Значну роль у цьому відіграє пристосованість до різноманітних умов середовища, скоростиглість і пластичність $[15,17,18]$.

Перед селекціонерами стоїть завдання створити не лише сорти 3 комплексом біологічних і господарських ознак, а сорти-агроекотипи, що мають високий адаптивний потенціал і пластичність. Властивість сортів формувати високий урожай при відмінних, не звичних для них умов пов'язана, швидше всього, зі спадковою здатністю сорту до модифікаційної мінливості. Завдяки високій пластичності сорт може виходити за межі свого ареалу - пристосований до посушливої зони може поширитися в більш зволожену й навпаки. Проте основою для розповсюдження сор- ту залишається все ж спадкова пристосованість до тих чи інших умов [5].

Аналіз основних досліджень і публікацій, у яких започатковано розв'язання проблеми. Основоположник вчення про вихідний матеріал М. І. Вавилов неодноразово наголошував на важливості пристосованості сортів до конкретних умов вирощування й вказував на залежність поведінки сортів від кліматичних зон [2]. Відомо, що врожай проса формується в результаті росту і розвитку рослин у певних умовах. Повна відповідність умов росту біологічним потребам проса забезпечує максимальний урожай. Біологічні потреби, у свою чергу, обумовлені його походженням, належністю до однієї 3 екологогеографічних груп [12].

В умовах Лісостепу України результат по створенню урожайних, пристосованих до місцевих умов сортів можна отримати, використовуючи для гібридизації зразки степових екологогеографічних груп: української, поволзької і казахстанської [3, 8, 13]. Необхідно дотримуватися того, щоб один із батьків вирізнявся високою потенційною продуктивністю, а другий був стійким до несприятливих умов [9]. Як правило, за одного з батьків використовують місцевий сорт.

Мета досліджень - встановити норму реакції зразків проса різного еколого-географічного походження на умови вирощування в зоні південного Лісостепу України та виділення джерел за урожайністю зі стабільним проявом даної ознаки.

Матеріали і методи досліджень. Для комплексного вивчення та виділення зразків із господарсько корисними ознаками на Устимівській дослідній станції рослинництва Інституту рослинництва ім. В. Я. Юр'єва протягом трьох років (2008-2010) були задіяні 153 сортозразки різних еколого-географічних груп: степових поволзької, української та казахстанської, а також притяншанської, північної, лісостепової, передньоазіатської, середньоазіатської низинної, східноазіатської, індійської, саяно-алтайської, далекосхідної, монголо-бурятської. Вивчення колекційних 
зразків проводили згідно з методичними вказівками BIP [1]. Агротехніка - загальноприйнята для вирощування проса в південному Лісостепу України. Посів проводили в оптимальні строки. Повторність - триразова, посівна площа ділянки $-2 \mathrm{~m}^{2}$, облікова $-1 \mathrm{~m}^{2}$. Ширина міжрядь $-45 \mathrm{~cm}$, норма висіву - 100 схожих насінин на 1 погонний метр. Стандарти: Харківське 57, Миронівське 51, Київське 87, які розміщували на початку, в середині і в кінці кожного повторення. Через кожні 20 номерів висівали Національний стандарт Харківське 57. У період вегетації проводили фенологічні спостереження й польові дослідження. Для кожного зразка визначена тривалість міжфазних періодів. У лабораторних умовах проведено аналіз елементів структури урожаю, оброблено й узагальнено результати досліджень.

Результати досліджень. Роки вивчення колекційних зразків проса за метеорологічними умовами були контрастними, з різним рівнем забезпечення теплом і опадами. В 2008 році, на відміну від інших років вивчення, склалися сприятливі погодні умови для швидкого проростання та сходів проса. Цьому сприяли оптимальна температура повітря й значна вологість грунту. Протягом 10 днів після сходів випала значна кількість опадів, що суттєво вплинуло на ріст і розвиток зразків проса. Погодні умови червня також сприяли нормальному проходженню міжфазного періоду «сходи - викидання волоті» як за температурним $\left(20,4^{\circ} \mathrm{C}\right.$ за середнього багаторічного показника $19,5^{\circ} \mathrm{C}$ ), так і за малодощовим режимом (45 мм за норми 57 мм). Із попередніх років досліджень відомо, що дощі й низька температура повітря та грунту в період викидання волоті значно відтягують настання цієї фази. У липні перша декада була дощова - 73,8 мм опадів і прохолодна $\left(20,8^{\circ} \mathrm{C}\right)$, друга декада тепла $\left(22,1^{\circ} \mathrm{C}\right)$ і менш волога (27,6 мм), а третя - жарка $\left(26,1^{\circ} \mathrm{C}\right)$ і майже без опадів $(3,1$ мм) із високою вологістю повітря протягом місяця (88\%). Такі погодні умови сприяли росту рослин проса та розвитку вегетативної й генеративної систем. Травень 2009 року був теплим і дощовим. Відсутність опадів у кінці травня і на початку червня дещо прискорили проходження міжфазного періоду «сходи - викидання волоті», що, в свою чергу, вплинуло на висоту рослин під кінець фази викидання волоті: у 2009 році рослини проса були значно нижчими, ніж у попередні роки. У липні перша декада була дощова (37,6 мм опадів) і тепла, друга і третя декади - 3 незначною кількістю опадів і високою температурою повіт- ря. Середньомісячна температура повітря становила $23,4{ }^{\circ} \mathrm{C}$ при багаторічному показнику $21,0{ }^{\circ} \mathrm{C}$. Такі погодні умови сприяли прискореному розвитку вегетативної та генеративної систем проса. Період вегетації був сформований із дещо коротшого за тривалістю міжфазного періоду «сходи - викидання волоті» й досить короткого періоду «викидання волоті - достигання». Для вегетаційного періоду 2010 року негативними виявилися мала кількість опадів (9,5 мм за 22 доби) в поєднанні $з$ високими температурами (до $38^{\circ} \mathrm{C} 9 . \mathrm{VI}$ ) у червні, коли у проса проходять фази онтогенезу від кущіння до викидання волоті. Швидке i дружнє достигання всіх зразків відбулося через високу температуру повітря у кінці липня (середньодобова $26,6^{\circ} \mathrm{C}$ ) та в першій декаді серпня (середньодобова $30,4{ }^{\circ} \mathrm{C}$ ). Зауважимо, що у 2010 році вегетаційний період усіх без винятку зразків проса був найкоротшим за останні 10 років. Вказані погодні умови під час вегетації дають підставу вважати 2008 рік оптимальним для вирощування проса, 2009 - менш сприятливим, а 2010 рік - посушливим.

Колекційні зразки за походженням були представлені 34 країнами світу. Найбільше зразків 3 України (56 зразків), Росії (32 зразки), Казахстану (9 зразків) (табл. 1).

Такий різноманітний географічний набір зразків дав змогу виділити країни, яким слід віддавати пріоритет інтродукції під конкретні селекційні програми. Основними показниками продуктивності рослини є маса зерна з рослини і волоті, довжина волоті та їі озерненість. За урожайністю найвищі показники мали зразки 3 Японії -

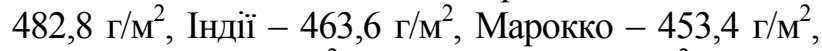

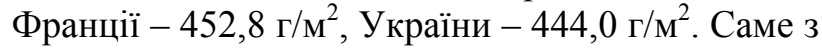
цих країн доцільно залучати зразки при спрямуванні селекційної роботи на підвищення загальної урожайності зерна. Найменшу врожайність мали зразки 3 Кенії $\left(75,2\right.$ г/ $\left.{ }^{2}\right)$, Югославії $\left(106,1 \Gamma / \mathrm{M}^{2}\right)$, Іраку $\left(122,3 \Gamma / \mathrm{M}^{2}\right)$. Це пізньостиглі й досить пізньостиглі зразки, які в нашій зоні формують низький урожай зерна

В оптимальному для вирощування проса 2008 році в середньому по набору колекційних зразків отримано найвищий урожай зерна - 401,6 г/м² (табл. 2). Незважаючи на посушливі умови, що склалися в період вегетації у 2010 році, середній урожай був дещо вищим, ніж у рік із більшою кількістю опадів (2009). Це ще раз доводить, що просо - посухостійка культура і формує досить високий врожай у низьких по вологозабезпеченню умовах. В усі роки вивчення коефіцієнт варіації даної ознаки був високим: $\mathrm{V}=22,8-31,6$ \%. 
СІЛЬСЬКЕ ГОСПОДАРСТВО. РОСЛИННИЦТВО

\section{1. Урожайність та ї̈ основні елементи залежно від географічного походження зразків проса}

\begin{tabular}{|c|c|c|c|c|c|c|c|c|}
\hline \multirow{2}{*}{$\begin{array}{c}\text { Країна } \\
\text { походження }\end{array}$} & \multirow{2}{*}{$\begin{array}{c}\text { К-сть } \\
\text { зразків, } \\
\text { шт. }\end{array}$} & \multirow{2}{*}{$\begin{array}{l}\text { Урожай- } \\
\text { ність, } \\
\text { г/м² }\end{array}$} & \multicolumn{3}{|c|}{ Маса зерна, г } & \multicolumn{3}{|c|}{ Елементи структури волоті } \\
\hline & & & $\begin{array}{r}1000 \\
\text { зерен }\end{array}$ & $\begin{array}{c}3 \\
\text { рослини }\end{array}$ & $\begin{array}{c}3 \\
\text { волоті }\end{array}$ & $\begin{array}{c}\text { довжина, } \\
\text { см }\end{array}$ & $\begin{array}{c}\text { ширина, } \\
\text { см }\end{array}$ & $\begin{array}{c}\text { к-сть } \\
\text { зерен, шт }\end{array}$ \\
\hline Аргентина & 1 & 251,4 & 5,8 & 1,7 & 1,5 & 29,4 & 3,1 & 254,3 \\
\hline Афганістан & 3 & 252,4 & 6,1 & 3,0 & 2,5 & 26,7 & 3,1 & 409,3 \\
\hline Бельгія & 1 & 205,6 & 6,0 & 2,7 & 2,4 & 30,4 & 3,2 & 417,3 \\
\hline Болгарія & 1 & 409,2 & 5,9 & 4,0 & 3,9 & 29,3 & 3,1 & 656,3 \\
\hline $\begin{array}{l}\text { Великобри- } \\
\text { танія }\end{array}$ & 1 & 379,3 & 5,7 & 2,4 & 2,3 & 36,7 & 3,0 & 372,7 \\
\hline Індія & 2 & 463,6 & 6,7 & 3,6 & 3,4 & 27,9 & 3,1 & 557,0 \\
\hline Ірак & 3 & 122,3 & 6,5 & 1,1 & 1,1 & 23,3 & 2,5 & 190,6 \\
\hline Iран & 1 & 365,4 & 7,0 & 3,4 & 3,2 & 28,5 & 3,1 & 522,3 \\
\hline Іспанія & 2 & 179,1 & 6,8 & 1,5 & 1,4 & 29,9 & 4,0 & 231,5 \\
\hline Італія & 1 & 344,7 & 6,0 & 4,5 & 3,7 & 28,1 & 3,0 & 629,7 \\
\hline Казахстан & 9 & 376,2 & 5,7 & 3,9 & 3,6 & 28,7 & 3,6 & 605,3 \\
\hline Канада & 1 & 344,9 & 6,0 & 2,6 & 2,4 & 37,5 & 5,0 & 386,7 \\
\hline Кенія & 1 & 75,2 & 6,9 & 1,6 & 1,3 & 33,7 & 2,5 & 203,7 \\
\hline Китай & 5 & 228,8 & 6,5 & 2,3 & 2,3 & 32,1 & 3,1 & 368,7 \\
\hline Корея & 1 & 440,5 & 7,3 & 4,5 & 4,2 & 26,5 & 3,4 & 587,7 \\
\hline Лівія & 1 & 242,8 & 6,7 & 1,9 & 1,7 & 32,6 & 3,4 & 281,7 \\
\hline Марокко & 1 & 453,4 & 6,3 & 6,2 & 5,8 & 34,2 & 4,3 & 937,0 \\
\hline Мексика & 1 & 367,4 & 6,3 & 4,3 & 4,0 & 31,1 & 2,9 & 643,7 \\
\hline Молдова & 1 & 233,7 & 7,9 & 3,2 & 2,4 & 19,5 & 2,6 & 339,3 \\
\hline Монголія & 3 & 271,6 & 6,3 & 3,7 & 3,3 & 24,8 & 4,9 & 534,3 \\
\hline Непал & 1 & 223,7 & 7,2 & 3,6 & 3,6 & 35,1 & 2,9 & 511,3 \\
\hline Німеччина & 1 & 348,5 & 6,0 & 1,7 & 1,7 & 36,3 & 6,8 & 281,0 \\
\hline Польща & 1 & 368,3 & 6,4 & 1,8 & 1,8 & 22,4 & 2,7 & 285,3 \\
\hline Португалія & 1 & 225,2 & 6,1 & 2,7 & 2,4 & 28,6 & 2,8 & 366,7 \\
\hline Росія & 32 & 366,6 & 5,9 & 4,2 & 3,8 & 27,3 & 3,3 & 596,3 \\
\hline Сирія & 1 & 278,7 & 7,0 & 2,6 & 2,4 & 28,8 & 3,3 & 407,7 \\
\hline США & 3 & 403,7 & 6,4 & 5,1 & 5,0 & 30,5 & 3,8 & 713,8 \\
\hline Туреччина & 3 & 397,9 & 6,3 & 4,0 & 3,6 & 25,7 & 3,5 & 615,9 \\
\hline Угорщина & 2 & 334,2 & 6,6 & 3,9 & 3,5 & 22,5 & 3,5 & 561,7 \\
\hline Узбекистан & 5 & 369,9 & 6,3 & 3,4 & 3,1 & 29,5 & 3,2 & 466,9 \\
\hline Україна & 56 & 444,0 & 6,9 & 5,7 & 5,1 & 31,3 & 3,9 & 750,6 \\
\hline Франція & 1 & 452,8 & 6,5 & 7,4 & 6,0 & 26,3 & 4,0 & 861,7 \\
\hline Югославія & 1 & 106,1 & 6,0 & 1,2 & 1,1 & 30,8 & 3,1 & 195,0 \\
\hline Японія & 1 & 482,8 & 5,8 & 4,7 & 4,2 & 26,8 & 3,2 & 621,0 \\
\hline
\end{tabular}

2. Варіювання урожайності зразків проса та їі складових елементів залежно від погодних умов вирощування

\begin{tabular}{|c|c|c|c|c|c|c|c|c|c|}
\hline \multirow{2}{*}{ Ознака } & \multicolumn{3}{|c|}{2008 рік } & \multicolumn{3}{|c|}{2009 рік } & \multicolumn{3}{|c|}{2010 рік } \\
\hline & x cep & $\min -\max$ & $\mathrm{V}, \%$ & $p$ & $\min -\max$ & $\mathrm{V}, \%$ & cep & $\min -\max$ & $\mathrm{V}, \%$ \\
\hline Урож & 401,6 & $38,3-6$ & 31,6 & 372,4 & 31,0 & 28,2 & 386,7 & $66-5$ & 22,8 \\
\hline Maca 1 & & 4,3 & 16,8 & 6,2 & 4,4 & 15,2 & 6,3 & $5,($ & 13,8 \\
\hline Вис & 13 & $97-174$ & 10,7 & 112,8 & 55,2 & 16,7 & 19,7 & $78,1-1$ & 14,3 \\
\hline Mac: & 5 & $0,4-13,3$ & 42 , & 4 & 8 & 58,0 & 4,0 & $0,89-9,51$ & 42,3 \\
\hline До & 29,6 & $16,0-43,1$ & 17,7 & 28,7 & $15,2-59,6$ & 18,3 & 30,1 & $14,6-47,8$ & 16,4 \\
\hline Іирина & 3,8 & $2,0-7,0$ & 25,6 & 4,0 & $1,5-19,3$ & 45,0 & 3,0 & $1,0-6,0$ & 27,5 \\
\hline Maca 3 & 4,9 & $3-11,8$ & 41,8 & 3,8 & 0,3 & 54,5 & 3,66 & $0,89-8,55$ & 40,8 \\
\hline -сть зерен із & 751 & $47-1719$ & 38,2 & 566 & $55-1488$ & 47,1 & 582 & $178-1166$ & 33,6 \\
\hline
\end{tabular}


Маса 1000 зерен - одна з ознак, що визначає продуктивність зерна з однієї рослини і $є$ вкрай важливим показником для визначення технологічної цінності сорту. На мінливість цієї ознаки вказують дослідники Р. В. Третьяков, В. І. Михайлець, Р. Р. Хайретдінова $[11,19,20]$. Маса 1000 зерен у різних зонах і в різні роки має досить стійку кореляцію з показником урожайності $(r=0,22-0,62)$ [15]. Підвищення маси 1000 зерен має суттєве значення для підвищення продуктивності проса $[8,10]$. У середньому по досліду найбільш крупне зерно формували зразки з Молдови, Кореї, Непалу, Ірану і Сирії. Найменшу масу 1000 зерен мали зразки з Великобританії, Казахстану, Аргентини, Японії, Росії.

Коливання маси 1000 зерен, на думку окремих дослідників [4], передусім зумовлене умовами вирощування, ніж сортовими особливостями. Вони вважають, що найкрупніше зерно формується за тривалого і прохолодного періоду від викидання волоті до достигання. Як надлишок, так і нестача вологи в цей період однаково зменшують крупність зерна. Маса 1000 зерен, як i урожайність, найбільшою була в 2008 році. У багатьох зразків вона перевищила 8 г, що для проса $\epsilon$ досить високим показником. Крупнозерне виповнене зерно сформували середньостиглі зразки лісостепової і степової української еколого-географічних груп. В інші два роки вивчення маса 1000 зерен знаходилася майже на одному рівні. Коефіцієнт варіації в усі роки був середнім ( $\mathrm{V}=13,8-16,8 \%)$.

Інші результати ми маємо по такому елементу структури урожаю, як висота рослини. При достатньому зволоженні на початку вегетації в 2008 році середне групове значення висоти рослин було значно вище, ніж в умовах 2009 і 2010 років, які характеризувалися меншою кількістю опадів на ранніх етапах розвитку рослин. Саме в цей період просо інтенсивно росте і збільшує вегетативну масу. Найменшу висоту мали зразки монголо-бурятської, саяно-алтайської і північної еколого-географічних груп. Високорослими виявилися зразки східноазіатської та передньоазіатської еколого-географічних груп. Висота рослин є найбільш константною ознакою (V=10,7-16,7 \%).

Вирішальну роль у збільшенні урожаю проса має озерненість і маса зерен із кожної волоті [7, 16]. Покращання водозабезпечення і мінерального живлення, як встановив В. А. Самохвалов, позитивно впливає на ці показники [14]. В нашому вивченні маса зерна 3 рослини і головної волоті найвищою була в 2008 році, дещо нижчою - в 2009 і 2010 роках, що підтверджує літе- ратурні дані про вплив погодних умов. Коефіцієнти варіації за цими показниками були високими в усі роки вивчення $\mathrm{V}=>40 \%$, що свідчить про наявність у колекції різноманітних генотипів i можливість ефективного добору за ознакою «продуктивність рослини».

Як показали дослідження Р. Р. Хайретдінової [21], довжина волоті - досить мінлива ознака, що залежить від погодних умов і особливо від вологості грунту. Значною мірою ця ознака варіювала у зразків із розлогими і рідкорозлогими типами волоті монголо-бурятської, далекосхідної, передньоазіатської, середньоазіатської гірської, притяншанської груп, що вказує на їх меншу посухостійкість у порівнянні з групами, що відносяться до стиснутого підвиду. За ознакою «довжина волоті» за роки досліджень отримано середній коефіцієнт варіації: $\mathrm{V}=16,4-18,3 \%$. За шириною волоті зразки проявили більший поліморфізм: $\mathrm{V}=25,6-45,0 \%$. Велике різноманіття показали зразки також за кількістю зерен із волоті: $\mathrm{V}=33,6-47,1 \%$.

За урожайністю та іiі структурних елементах найвищий коефіцієнт варіації був у оптимальному для вирощування проса 2008 році, коли зразки залежно від своїх сортових особливостей проявили найбільше різноманіття даних ознак.

У таблиці 3 наведені зразки проса, що виділилися за урожайністю зерна в роки вивчення. У переважної більшості зразків показники основних елементів структури урожаю перевищують аналогічні показники сортів-стандартів. Із-поміж виділених і наведених зразків значна частина це лінії, створені в лабораторії селекції проса Інституту рослинництва ім. В. Я. Юр'єва. Ознака «урожайність» найменше варіювала у стандартів Київське 87, Миронівське 51 і таких зразків: UDS00775 з Індії, UDS05760 сел. лін. 98-4150, UDS05777 сел. лін. 94-11011, UDS05759 сел. лін. 98-4130, UDS05761 сел. лін. 98-4195, UDS00725 3 Харківської обл., UDS05756 сел. лін. 98-2562, UDS05009 з Бєлгородської області. Серед елементів структури урожаю високоврожайних зразків незначну варіацію мали показники: маса 1000 зерен, висота рослини, довжина волоті - всі інші елементи мали підвищену варіабельність ознак. За даними Ю. С. Колягіна, кореляційний зв'язок відсутній між масою зерна 3 волоті й масою 1000 зерен, а також між довжиною волоті та масою 1000 зерен. Це необхідно враховувати при селекції проса на крупність зерна і продуктивність рослин [6]. У наших дослідженнях ми отримали дещо інші результати. Виявлено існування середнього позитивного зв'язку між 
СІЛЬСЬКЕ ГОСПОДАРСТВО. РОСЛИННИЦТВО

\section{3. Вихідний матеріал для створення високоврожсайних сортів проса, 2008-2010 рр.}

\begin{tabular}{|c|c|c|c|c|c|c|c|c|c|c|c|}
\hline \multirow{2}{*}{$\begin{array}{l}\text { № кат. } \\
\text { УДС }\end{array}$} & \multirow{2}{*}{$\begin{array}{l}\text { Назва або похо- } \\
\text { дження зразка }\end{array}$} & \multicolumn{2}{|c|}{$\begin{array}{c}\text { Урожай } \\
\text { зерна, г/м² }\end{array}$} & \multicolumn{2}{|c|}{$\begin{array}{l}\text { Мaca } 1000 \\
\text { зерен, г }\end{array}$} & \multicolumn{2}{|c|}{$\begin{array}{l}\text { Маса зерна } \\
3 \text { рослини, Г }\end{array}$} & \multicolumn{2}{|c|}{$\begin{array}{c}\text { Маса зерна } \\
\text { з волоті, } \Gamma\end{array}$} & \multicolumn{2}{|c|}{$\begin{array}{l}\text { Кількість } \\
\text { зерен, шт. }\end{array}$} \\
\hline & & X cep & $\mathrm{V}, \%$ & X cep & $\mathrm{V}, \%$ & X cep & $\mathrm{V}, \%$ & X cep & $\mathrm{V}, \%$ & cep & $\mathrm{V}, \%$ \\
\hline 1 & $\mathbf{y}$ & 500,2 & 12,33 & 7,40 & 7,15 & 6,50 & & 621 & & 53,3 & 5,26 \\
\hline & & 495,3 & & 30 & 4,94 & 32 & & 1 & & & 3,35 \\
\hline & & & & & & & & & & & \\
\hline & & & & & & 49 & & & & & \\
\hline & & & & & & & & & & &, 76 \\
\hline & & & & & 0,48 & & & & & & 93 \\
\hline & & & & 75 & & & & & &, 3 & 3,97 \\
\hline & & 31 & & 23 & 16,02 & 5,64 & & & & 52,0 & 4,77 \\
\hline & & & & 37 & & 49 & & $\pi 1$ & & 4,3 & ,98 \\
\hline & & & & & & & & & & & \\
\hline & & & & & & & & & & ,3 & 12 \\
\hline & & & & & & & & & & & 85 \\
\hline & & & & & & & & & & 884,0 & 0,84 \\
\hline & &, 7 & & 90 & 56 & 92 & & 13 & & 1148 & 24,55 \\
\hline & & & & & 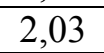 & 77 & & 44 & 70 & 02 & 30,31 \\
\hline & & & & & & & & & 27 & 59,0 & 0,55 \\
\hline & & & & & & & & & & & \\
\hline & & & & & 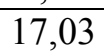 & & & & & 98,3 & 4,24 \\
\hline & & & & & & & & & & & 3,44 \\
\hline & & & & & 8,8 & 22 & & 00 & & 67,7 & 9,12 \\
\hline & & & & & & 8,07 & & 45 & 07 & 96,7 & 13,11 \\
\hline & & & & 8, & 13,80 & 5,54 & & 5,09 & 44 & 18,3 & 36,07 \\
\hline 09 & ббл. & 501,2 & 5,0 & 6,72 & 7,89 & 4,23 & 16,08 & 3,85 & 21,69 & 606,7 & 35,75 \\
\hline
\end{tabular}

4. Оцінка практичної цінності зразків проса за ознакою «урожайність зерна»

\begin{tabular}{|c|c|c|c|c|c|c|c|c|}
\hline № кат. УДС & Назва зразка & $\begin{array}{l}\text { Країна по- } \\
\text { ходження }\end{array}$ & $\begin{array}{l}\text { Урожай } \\
\text { зерна, } \\
\text { г/м }^{2}\end{array}$ & $\begin{array}{c}\text { Геноти- } \\
\text { повий } \\
\text { ефект }\end{array}$ & Ранг & $\begin{array}{c}\text { Коефi- } \\
\text { цієнт } \\
\text { регресії }\end{array}$ & Ранг & $\begin{array}{c}\text { Сума } \\
\text { рангів }\end{array}$ \\
\hline UDS02051 & St-Харківське 57 & Україна & 500,23 & 130,9738 & 1 & 3,82 & 3 & 4 \\
\hline UDS01297 & M 82-7951 & Україна & 558,67 & 172,1770 & 1 & 1,06 & 2 & 3 \\
\hline UDS05516 & Слобожанське & Україна & 550,50 & 163,4436 & 1 & 5,37 & 3 & 4 \\
\hline UDS00775 & Місцевий & Індія & 545,56 & 158,5103 & 1 & 0,06 & 1 & 2 \\
\hline UDS05760 & Сел. лін. 98-4150 & Україна & 540,83 & 153,7769 & 1 & 0,36 & 2 & 3 \\
\hline UDS05777 & Сел. лін. 94-11011 & Україна & 533,06 & 161,6770 & 1 & 1,53 & 2 & 3 \\
\hline UDS01293 & M 81-7152 & Україна & 531,83 & 144,7769 & 1 & 4,18 & 3 & 4 \\
\hline UDS05763 & Сел. лін. 95-8136 & Україна & 528,67 & 141,8436 & 1 & 6,01 & 3 & 4 \\
\hline UDS05757 & Сел. лін. 98-3151 & Україна & 528,00 & 140,9436 & 1 & 3,02 & 3 & 4 \\
\hline UDS05759 & Сел. лін. 98-4130 & Україна & 524,50 & 137,4436 & 1 & 1,84 & 3 & 4 \\
\hline UDS05761 & Сел. лін. 98-4195 & Україна & 520,28 & 137,5437 & 1 & 1,52 & 2 & 3 \\
\hline UDS05753 & Сел. лін. 96-4219 & Україна & 519,72 & 132,6770 & 1 & 4,00 & 3 & 4 \\
\hline UDS05749 & Сел. лін. 94-2295 & Україна & 517,83 & 130,7769 & 1 & 5,20 & 3 & 4 \\
\hline UDS00725 & Місцевий & Україна & 517,78 & 130,7103 & 1 & 3,21 & 3 & 4 \\
\hline UDS05752 & Сел. лін. 96-4204 & Україна & 517,39 & 130,3436 & 1 & 4,04 & 3 & 4 \\
\hline UDS01280 & Флявум 665-28 & Україна & 516,17 & 129,1103 & 1 & $-0,84$ & 1 & 2 \\
\hline UDS05756 & Сел. лін. 98-2562 & Україна & 514,50 & 127,4436 & 1 & 2,84 & 3 & 4 \\
\hline UDS01294 & M 83-8272 & Україна & 511,78 & 124,7437 & 1 & 7,32 & 3 & 4 \\
\hline UDS02195 & Місцевий & Україна & 510,33 & 123,2770 & 1 & 4,05 & 3 & 4 \\
\hline UDS05769 & Сел. лін. 98-3237 & Україна & 508,67 & 121,6103 & 1 & 4,19 & 3 & 4 \\
\hline \multirow[t]{2}{*}{ UDS05009 } & Місцевий & Росія & 501,22 & 114,1436 & 1 & 1,7 & 3 & 4 \\
\hline & $H I P_{05}$ & & & 112,3033 & & 0,66 & & \\
\hline
\end{tabular}


масою зерна 3 волоті та масою 1000 зерен $\mathrm{r}=$ 0,274-0,386 та негативного зв'язку між довжиною волоті і масою 1000 зерен $\mathrm{r}=0,065-0,361$.

Для того, щоб отримати надійну оцінку зразків і виявити найбільш пристосовані форми за ознакою «урожайність зерна», проводили екологічне сортовипробування методом «сорт х рік». Iз даних таблиці 4 бачимо, що найбільшу селекційну цінність представляють такі зразки: UDS00775 з Індіï, UDS01280 Флявум 665-28, UDS01297 M 82-7951, UDS05760 сел. лін. 98-4150, UDS05777 сел. лін. 94-11011, UDS05761 сел. лін. 98-4195 із сумою рангів 2-3. Ці зразки мають не лише високий рівень прояву ознаки, але й високу їі стабільність. Інші сортозразки також мають високий рівень прояву ознаки, хоча іiі прояв значно залежить від умов вирощування. Результати кореляційного аналізу показали, що найбільш тісний зв'язок існує між урожайністю і такими іiі елементами: маса зерна 3 волоті $\mathrm{r}=0,423-0,688$, маса зерна 3 рослини $\mathrm{r}=0,499-0,628$, кількість зерен із волоті $\mathrm{r}=0,484-0,654$, довжина волоті $\mathrm{r}=0,210-0,301$, маса 1000 зерен $\mathrm{r}=0,186-0,275$. Незначний негативний зв'язок існує 3 тривалістю вегетаційного періоду $r=-0,08 \ldots-0,310$. Зв'язок із показником «ширина волоті» змінюється в залежності від умов року вирощування. Так, у 2008 році коефіцієнт кореляції становив $\mathrm{r}=-0,02$ (незначний негативний), тоді як у 2009-2010 роках, відповід-

\section{БІБЛІОГРАФІЯ}

1. Агафонов Н. П. Изучение мировой коллекции проса : методические указания / Н. П. Агафонов, А. Ф. Курцева. - Л.: Издательство ВИР, 1988. $30 \mathrm{c}$.

2. Вавилов Н. И. Проблема происхождения культурных растений в современном понимании / Н. И. Вавилов // Отд. оттиск из кн.: Достижение и перспективы в области прикладной ботаники, генетике и селекции. - М., 1929. - С. 11-22.

3. Горбачёва С. Н. Создание исходного материала для селекции проса на повышенное содержание белка и незаменимых аминокислот в условиях восточной Лесостепи Украины: дис. ... канд. с.-х. наук : 06.01.05 / Горбачёва Светлана Николаевна. - Х., 1994. - 159 с.

4. Джумагулова Л. И. Потребительские свойства проса Казахстана / Л. И. Джумагулова, И. Р. Рахимбаев // Вестник сельскохозяйственной науки (Алма-Ата). -1969. - № 12. - С. 77-79.

5. Ильин B. A. Гибридизация - основной метод селекции проса / В. А. Ильин // Всесоюз. совещание по селекции, семеноводству и агротехнике проса : материалы ... 29-31 июля 1969 г. : ста- но, $r=0,326-0,405$ (середній позитивний).

Висновки. Таким чином, вивчення генофонду проса в різних погодних умовах дало змогу встановити значні відмінності показника «урожайність» та іiі складових елементів у залежності від географічного походження та екологогеографічних груп зразків. Найбільш врожайними виявилися зразки походженням 3 України, Японіï, Індіï, Марокко і Франції. Тому при інтродукції, спрямованій на залучення вихідного матеріалу із високим біологічним потенціалом урожайності, слід надавати перевагу сортозразкам саме із цих країн. Високоврожайні зразки відносяться до степової української, лісостепової та індійської еколого-географічних груп.

За роками найменше варіюють такі елементи урожайності: маса 1000 зерен, висота рослини, довжина волоті. Досить значний кореляційний зв'язок існує між урожайністю та їі складовими: маса зерна 3 волоті, маса зерна 3 рослини, кількість зерен із волоті. Найбільшу цінність для селекції на високу урожайність мають зразки UDS00775 з Індії, UDS01280 Флявум 665-28, UDS01297 M 82-7951, UDS05760 сел. лін. 98-4150, UDS05777 сел. лін. 94-11011, UDS05761 сел. лін. 98-4195 із високою стабільністю даної ознаки.

Виділені зразки рекомендується включати в селекційний процес для виведення високоврожайних пластичних сортів проса.

тьи. - Саратов, 1970. - С. 42-58.

6. Колягин Ю. С. Селекция проса в условиях интенсивного земледелия Центрально-черноземной зоны : автореф. дис. ... докт. с.-х. наук : спец. 06.01 .05 «Селекция и семеноводство растений»/ Ю. С. Колягин. - СПб., 1993. - 54 с.

7. Корнилов А. А. Просо. / Корнилов А. А. - М. : Сельхозгиз, 1957. - 255 с.

8. Куризева $A$. Ф. Биологическая и технологическая характеристика эколого-географических групп проса в различных условиях выращивания : автореф. дис. ... канд. с.-х. наук : спец. 06.01.05 «Селекция и семеноводство растений» / А. Ф. Курцева. - Л., 1981. - 25 с.

9. Лысак C. А. Выведение сортов проса методом гибридизации / С. А. Лысак // Всесоюз. совещание по селекции, семеноводству и агротехнике проса : материалы ... 29-31 июля 1969 г. : статьи. - Саратов, 1970. - С. 59-68.

10. Лузина 3. П. Морфобиологические особенности и селекционная ценность коллекции проса в условиях Северного Казахстана : автореф. дис. ...канд. с.-х. наук : спец. 06.01.05 «Селекция и 
семеноводство растений» / 3. П. Лузина. - Л., 1974. - $24 \mathrm{c}$.

11. Михайлець B. I. Місцевий сортовий склад проса західних районів УРСР та його селекційне значення / В. І. Михайлець // Тез. докл. 5-ой аспирантской конф. НИИ земледелия и животноводства зап. р-нов КССР. : тезисы докл. - Львов, 1961. - C. 109-110.

12. Огурцова Л. И. Изучение коллекции проса в условиях левобережья Куйбышевской области : автореф. дис. .... канд. с.-х. наук : спец. 06.01 .05 «елекция и семеноводство растений» / Л. И. Огурцова. - Л., 1970. - 22 с.

13. Подвезько В. В. Оценка сортового разнообразия проса в условиях Полтавской области : автореф. дис. ... канд. с.-х. наук : спец. 06.01 .05 «Селекция и семеноводство растений» / В. В. Подвезько. - Л., 1978. - 20 с.

14. Самохвалов В. А. Влияние орошения и удобрений на урожай зерна и качество крупы проса : автореф. дис. ... канд. с.-х. наук : спец. 06.01.05 «Селекция и семеноводство растений» / В. А. Самохвалов. - Саратов, 1973. -21 с.

15. Сергеева A. T. Технологические свойства коллекционных образцов проса, выращенных в условиях Поволжья / А. Т. Сергеева, А. Ф. Курцева // Науч.-техн. бюл. ВИР. - 1983. - Вып. 135. - C. 54-58.
16. Сергеева A. T. Продуктивность и технологические качества проса в условиях Полтавской области / А. Т. Сергеева, А. Ф. Курцева, Е. С. Подвезько // Науч.-техн. бюл. ВИР. - 1979. - Вып. 94. C. 46-49.

17. Сиротин A. A. К характеристике сортов проса, различных по скороспелости / А. А. Сиротин, Л. В. Сиротина, Н. П. Агафонов // Труды по прикл. бот., ген. и сел. - Л., 1973. - Т. 51. Вып. 1. - С. 200-202.

18. Тарасов С. Ф. О признаках отбора при селекции засухоустойчивости сортов проса / С. Ф. Тарасов // Повышение засухоустойчивости зерновых культур. - М., 1970. - С. 125-126.

19. Третьяков Р. В. Оценка коллекции проса на засухоустойчивость в условиях Западного Казахстана : автореф. дис. ... канд. с.-х. наук : спец. 06.01 .05 «Селекция и семеноводство растений» / Р. В. Третьяков. - Л., 1966. -28 с.

20. Хайретдинова Р. Р. Исходный материал для селекции проса в условиях Башкирии : автореф. дис. ... канд. с.-х. наук : спец. 06.01.05 «Селекция растений» / Р. Р. Хайретдинова. - Л., 1979. $21 \mathrm{c}$.

21. Хайретдинова Р. Р. Селекция проса в Башкирии / Р. Р. Хайретдинова // Биология и агротехника с.-х. культур. - Ульяновск, 1973. - С. 184195. 